\title{
The Research on Enhancing the Competitiveness of Tourism Industry in Hubei Province under the Background of One Belt and One Road
}

\author{
Minghui Long and Qiuju Xu* \\ Wuhan Donghu University, Wuhan, Hubei, China \\ 642604051@qq.com \\ *The corresponding author
}

\begin{abstract}
Keywords: One belt and one Road; Tourist industry; Competitiveness
\end{abstract}
\begin{abstract}
Since the implementation of the national "One Belt and One Road" strategy, the tourism industry of Hubei actively participates in the "One Belt and One Road" tourism cooperation with countries and territories along the road to deepen the regional tourism cooperation. The tourism industry is a comprehensive industry involving many departments, In the time that our country is planning the tourism development ideas during the "13th Five-Year" and accelerating the integration of the "One Belt and One Road" strategy, this paper combined the advantage of development of tourism industry in Hubei Province to analyzes the new norm facing the tourism industry in Hubei Province, and put forward overall competitiveness promotion path to Hubei tourism industry under the "One Belt and One Road" strategy.
\end{abstract}

\section{Introduction}

In recent years, the process of world economic integration is accelerating, and the pattern of international investment and trade and the trade rules of multilateral investment are planning to adjust. The "One Belt and One Road" national strategy proposed by President Xi Jinping's is steadily advancing. The concept of "One Belt and One Road" was firstly put forward in 2013, when President Xi Jinping visited to South and Central Asia to discuss about the blueprint of jointly build modern Silk Road economic belt and the 21st-Century Maritime Silk Road with neighboring countries. In 2014, at the Asia Pacific Economic Cooperation conference, China laid special stress on the issue of strengthening cooperation with neighboring countries in infrastructure and Internet construction. The "One Belt and One Road" strategy adheres to open spirit of regional cooperation and commits to maintaining the global free-trade system and open world economy, which is also an active exploration of international cooperation and a new model of global governance, and will add new positive energy to world peace and development.

\section{The Relevant Theory of "One Belt And One Road"}

The connotation of "One Belt and One Road" is very profound, which is an integral long-term development strategy, and a grand strategic vision that aims at constructing a reciprocal and win-win interest community and a jointly prosperous community of common destiny. It absorbs the essence of Western geopolitics and gives new content to the development of Geopolitics in 21st Century. The "One Belt and One Road" strategy of China not only includes the ideas of economic development and international geopolitical cooperation, but also embodies the friendly spirit of good-neighborliness, which provides an important theoretical support for building a harmonious world and regional cooperation.

According to the theory of regional integration, sub regional cooperation is an important part of the theory of regional economic integration. The extensive implement of sub regional cooperation can accelerate the process of regional integration The "One Belt and One Road" strategy is a typical example of the sub regional cooperation form, a joint enterprise among the neighboring countries, and a cross-border shared zone, which aims at transforming the advantages of security and mutual trust, geographical proximity and economic complementarity into practical cooperation and 
common development.

The new economic geography, also known as spatial economics, springs up related to the limitation of economic theory. Generally speak, the theory of economics ignores the reality of space, and argues that the factors of production can be transferred from one activity space to another without the need of freight. After 1960s, especially with the globalization and regionalization of the world economy, the difficulties encountered by the mainstream economic theory in explaining the development of the real economy are becoming more and more serious. Therefore, the western economists represented by Paul Krugman return to the perspective of economic geography. Based on the theory of marginal income increasing, imperfect competition and path dependence, their theory expands the analysis of economic activities such as spatial agglomeration and globalization. In the book of Development, Geography and Economic Theory, Krugman analyzes the tradition of the study of spatial economy and divides it into five aspects: German geometry, social physics, cumulative causality, local external economy and land rent and land use.

The point axis development theory is an extension of the growth pole theory. From the perspective of regional economic development, the economic center is always focusing on a few of areas of good conditions that appear dot distribution. With the development of economy, the economic center increases gradually. Transport lines, power supply lines, water supply lines any other lines are connected to each other among these points due to the exchange of production factors, which is the axis. These axes are primary to serve the regional growth pole, however, once formed, it is also attractive to the population and the industry, which will attract the population and industry gathering along both sides of the axis, and generate new growth points. Point axis development can be understood as the development of large and small areas of the economic center (point) along the traffic lines to the underdeveloped areas to develop in depth.

\section{The Tourism Industry and the "One Belt And One Road" Construction}

"One Belt and One Road" refers to "Silk Road Economic Belt" and "21st-Century Maritime Silk Road". It will make the best of existing double multilateral mechanism and existing and effective regional cooperate platform among China and the relevant countries. "One Belt and One Road" throughout Eurasia, connecting the Asia Pacific Economic Circle to the East and entering into European Economic circle to the West. Whether in developing the economy, improving people's livelihood, or to deal with the crisis and speed up the adjustment, many countries along the line share common interests with China, which is a new pattern of China's opening up to the outside world.

Tourism Plays an Important Role in Deepening Connection to People Among the Countries Along the "One Belt and One Road" Line. The connection to people is the social foundation of "One Belt and One Road" construction. Tourism cooperation will not only enable both sides to get to know each other better and eliminate prejudice and misunderstanding, but also bring a large number of people, logistics, information flow and capital flow. In 2015, National Development and Reform Commission, Ministry of Foreign Affairs and Ministry of Commerce jointly issued the Vision and Actions on Jointly Building Silk Road Economic Belt and 21st-Century Maritime Silk Road, the file clearly put forward that we should strength the tourism cooperation, expand the scale of tourism and host the tourism promotion week, awareness month and other activities. Launch the international boutique tourist routes and tourism products with the characteristics of Silk Road jointly, improve tourist visa facilitation level among countries along the route, and promote the 21st-Century Maritime Silk Road cruise tourism cooperation; We need to promote border trade, tourism and cultural cooperation among Tibet and Nepal and other countries; We should increase the development and opening of Hainan international tourism island. According to the National Tourism Administration, during the "13th Five-Year" period, China will transport 150 million tourists to countries along the "One Belt and One Road" line, and \$200 billion will be consumed. At the same time, we will also attract 85 million tourists from these countries, and stimulate tourism consumption of about $\$ 110$ billion. Therefore, the development of tourism industry in Hubei province should seize the opportunity of "One Belt and One Road", 
deeply develops the cooperation in tourism, aims at resources, customers, markets and benefits sharing, and actively promote the market open to each other and jointly establish a tourism facilitation mechanism.

Inf rastructure Construction will greatly enhance the Accessibility of Tourism. The Silk Road is the collection of world's most elite tourism resources, assembling $80 \%$ cultural heritages of the world; which is also the most dynamic and potential gold tourism road in the world. Vision and Actions on Jointly Building Silk Road Economic Belt and 21st-Century Maritime Silk Road will help China's tourism industry develop from point to area, Infrastructure will be improved, especially the traffic conditions in the deep inland along the Silk Road in central and Western China. In the meantime, it will also attract the main tourist market in the Eastern enter into the destinations in Central and Western China where tourism resources are gathering, and promote the border tourism among neighboring countries and China's border provinces.

Promote Maritime Silk Road Tourism Cooperation in 21st-Century. The development of tourism is closely linked with the traffic. Accessibility of tourism traffic is an important factor that affects the flow of tourism elements among tourist destinations, which plays a vital role in the sustained, healthy and rapid development of tourism. Maritime Silk Road involving the port cities in eastern coast, will stimulate cruise tourism, marine tourism to leap to a big step. By simplifying visa procedures and customs procedures or even Visa-free methods, Maritime Silk Road not only attracts the world's three largest cruise company to open more home port and port routes, but also stimulates Chinese government and enterprises to invest in facility construction of cruise port, which will create a brighter future for Chinese enterprises to set up cruise ships and routes. The emergence of high-speed rail will become a powerful guarantee to reshape the brilliant of Silk Road. Nowadays the traffic network of Hubei province is increasingly perfect, which provides further strong support for Hubei tourism entering into the construction of "One Belt and One Road".

\section{Under the Background of the One Belt and One Road, he Tourism Industry in Hubei Province Faces New Normal.}

Since Chinese economic and social development stepped into the new normal, it becomes inevitable for the tourism industry in Hubei, as one of the important areas of modern service industry, to implement strategic adjustments and integrate into the new normal. All as mainly reflected in the following areas.

"13th Five-Year" Tourism Plan in Hubei put Forward New Goals. In August 2014, the State Council issued the opinions on promoting the reform and development of tourism, thus elaborating tourism in detail from the strategic level of One Belt and One Road, raising the tourism along silk road to the height of the country and making out a timetable to build tourism industry into a strategic pillar industry. During the " 13 th Five-Year" period, Hubei province will focus on promoting the tourism development throughout the whole province. The overall layout of tourism throughout Hubei is to make efforts to build a city-based, traffic-supported, open tourism strategic layout, which features on "one road, two poles and four corridors" with the space development strategy of "gold belt assuming overall situation, two poles leveraging its strengths, corridors connecting each other and plates developing rapidly". Tourism throughout Hubei aims not at wide range and completeness, nor small scale and elaboration, but developing tourism in moderate areas and scales. Tourism throughout Hubei aims not simply at tourist increase and scale expansion, but the integration of all elements and the improvement of the quality. Tourism throughout Hubei should adheres to the coordination between development and protection and focus on planning systematicness and functional coordination. Tourism throughout Hubei should sticks to the principle of putting protection first, developing tourism in an orderly way, utilizing tourist resources in a intensive and economic way and coordinating developments of all areas instead of becoming a hodgepodge of piling up. 
"One Belt and One Road" Strategy Established a New Positioning for Tourism Industry in Hubei. Tourism is a part of the national strategy of building "One Belt and One Road" as well as the most effective way in the construction of the Silk Road. Since the 12th Five-Year, the province's tourism reception and total revenue continued to maintain an average annual growth rate of two digits. Under the background of economic downward pressure, the tourism industry has maintained a strong momentum of development and burst with vigor and vitality. The tourism industry continues to give full play to its comprehensive advantages as a sunrise industry, livelihood industry and green industry, thus releasing its economic, social, ecological functions etc, and making positive contribution to expanding consumption, stabilizing growth, promoting employment, reducing poverty and benefiting livelihood.

Taking the opportunity of the national strategy of One Belt and One Road, collaborative development between Beijing, Tianjin and Hebei, as well as the Yangtze River Economic Zone, tourism integration in the various regions of the country is advancing with more extensive areas of cooperation and more enriched levels of cooperation, thus creating a huge space for the development of Hubei tourism through win-win cooperation. During the 13th Five-Year, Hubei, as the enrichment region and essence section of tourism resources along the Yangtze River as well as the important region of tourism demand spillover, tourism industry transfer and tourism investment in the Yangtze River Delta agglomerations, will become a core growth pole to the rise of the tourism in central China and a prime tourist resort in the Yangtze River Economic Zone.

Regional Tourism Presents a New Situation of Competition and Cooperation. In the areas along the "One Belt and One Road" and under the background of national construction of the "One Belt and One Road" tourism market, Hubei tourism will probably face a more complicated external environment and more intense regional and industrial competitions. "One Belt and One Road" involves 18 provinces, including 6 provinces in northwest China, namely Xinjiang, Shaanxi, Gansu, Ningxia, Qinghai, Inner Mongolia, 3 provinces in northeast China, namely Heilongjiang, Jilin, Liaoning, 3 provinces in southwest China, namely Guangxi, Yunnan, Tibet, 5 coastal provinces, namely Shanghai, Fujian, Guangdong, Zhejiang, Hainan and Chongqing in the inland area. In the case of the product homogeneity of Hubei tourism market and the lack of domestic supply of tourism products, Hubei will face more and more problems and difficulties in competing with Central Asia, some Southeast Asia countries as well as domestic countries in terms of tourists. In 2015, The Alliance of Culinary Tourism along the "One Belt and One Road" regions was established in Yinchuan and the Ningxia Declaration of The Alliance of Culinary Tourism along the "One Belt and One Road" regions was also released at the same time. The alliance was established with the leadership of World Association of Chinese Cuisine and the joint launch of 36 related departments, industrial organization and news media in the filed of catering, cooking and tourism in 16 provinces, municipalities and autonomous regions, namely Shaanxi, Gansu, Qinghai, Xinjiang, Ningxia, Inner Mongolia, Shanghai, Jiangsu, Zhejiang, Fujian, Shandong, Yunnan, Sichuan, covering all areas along the "One Belt and One Road". The alliance will work in the aspect of theoretical research, sports and festivals, brand cultivation, media promotion, talent cultivation and international exchanges, promoting the economic development and cultural exchanges in the areas along the "One Belt and One Road" in an all-round way, spreading excellent Chinese food culture and tourism culture, establishing and enhancing regional cooperation and interconnection of network between China and countries, areas along in the filed of food and tourism industry. It's obvious that in the development of the regional tourism in the areas along the "One Belt and One Road", competition and cooperation among regional industries will become an efficient way of connecting the "One Belt and One Road". Although the development momentum of competition and cooperation is pressing, Hubei province is still lack of regional tourism cooperation alliance and needs to make efforts to seize opportunities, so as to achieve development.

The Tourism Resources in the "One Belt and One Road" Areas are in Urgent Need of New Integration. Hubei province is a major tourism province in China, but not a strong tourism province, and the tourism industry haven't played its comprehensive and leading role in the modern service industry very well. What's more, the integration of "One Belt and One Road" tourism 
resources is not enough, and the cross-regional and inter-regional tourism resources and facilities are still segregated into some parts to a certain degree, failing to achieve unified development and cluster development. The natural landscape of Hubei province is mainly based on water resources and forest resources, but world-class or monopoly tourism resources are deficient in Hubei and the level of resources development is above the medium level. The development of tourism products and tourism market in Hubei province are relatively backward, failing to forming tourism products of high visibility and attractiveness. At the same time, cultural tourism resources in Hubei are also lack of depth of excavation.

Tourism Brand Building of the "One Belt and One Road" Needs Innovation. Cultural brand is a strong symbol of existence, representing the image and strength of a region and a country. Hubei province is rich in its history, but relatively backward in the building of cultural brand with single-variety tourism products of weak participatory. In addition, the tourism brand image still needs to be improved. The image of "delicately beautiful Hubei" still has deficiencies in difference recognition and universality cognition. What's more, tourism public services in Hubei province is relatively backward, resulting in relatively low popularity, satisfaction and reputation.

The Way of Interconnection with Countries along the "One Belt and One Road" is in Urgent Need of New Integration. "One Belt and One Road" runs throughout Europe, and it is a breakthrough to the implement of opening-up strategy in an all-round way under the new situation. At present, there lies great potential of interconnection between China and countries along the "One Belt and One Road" in tourism, for example, the continental and marine network and international air transportation network between China and Asia-Pacific, Europe need to be improved and comprehensive transportation system based on the interconnection by land, air and sea is still under construction and needs further integration and excavation.

\section{Suggestions on the Countermeasures of Tourism Industry in the Areas along the "One Belt and One Road" in Hubei}

A new Layout of Balancing Tourism Industry in the Areas along the "One Belt and One Road" in Hubei. Firstly, we should integrate resources and make tourism a new highlight of promoting the development of national economy. We should strengthen the integration of tourism resources and facilities and make efforts to promote cluster development of tourist attractions and tourist enterprises. What's more, we should build tourism brands of core competitiveness and important influence, and make it a compound industry covering multiple elements and industries, as well as a strategic pillar industry in national economy in Hubei and the flagship of tertiary industry, so as to promote the leaping-over development of tourism, and truly make the tourism industry a new highlight of the national economy and a pillar industry. Secondly, we should integrate industry, and make the tourism industry a new driven force of promoting the development of related industries, so as to turn Hubei into the core of the central tourism, the backbone of the Yangtze River tourism and the support of Chinese tourism. We should also strengthen the resource integration, production integration and service integration between tourism and related industries, and establish a tourism-driven industry linkage mechanism, so as to make the new tourism industry condition the most direct embodiment of the development of related industries.

Seek a New Model of Regional Tourism Cooperation and Development. Based on the comprehensive advantages of tourism, we should put it into a full play as a leading role in regional cooperation, and promote cross-regional exchanges and cooperation in an all-round way. We should also strengthen the cooperation with City Cluster in the Middle Reaches of the Yangtze River, Yangtze River Economic Zone and even provinces all over China, accelerating the development in the expansion of opening up, so as to achieve leaping-over development of Hubei tourism to a wider extent. In addition to strengthening the tourism cooperation between the two tourist circles and among each region in Hubei, we should actively promote the tourism cooperation with neighboring regions, areas along the Yangtze River, areas along the high-speed rail and even overseas areas, and expand constantly the development space of the tourism industry in Hubei. We should strengthen tourism cooperation with 10 provinces along the Yangtze River Basin, and on the 
basis of the Yangtze River Tourism Alliance, establish a new mechanism of cooperative development of the Yangtze River tourism, focusing on product portfolio, market interaction and management to achieve a breakthrough. [9]We should implement the "One Belt and One Road" strategy, and adapt to the new trend of tourism economic globalization, and vigorously promote domestic and international tourism cooperation. We should also implement the Vision and Actions on Jointly Building Silk Road Economic Belt and 21-Century Maritime Silk Road. We should carry out tourism cooperation among the cities along the tea road. In addition, we should advance the tourism strategic cooperation with the federal districts along the Volga River in Russian, and actively build the Hanxinou Railway, put the tourism train from Hubei province to central Asia and Russia by way of Xinjiang into use. Moreover, we should also open the Wuhan-Moscow tourism chartered flights and put forward and implement the tourism cooperation roadmap.

Bring Forth New Ideas in the Levels and Fields of the "One Belt and One Road" Tourism Cooperation in Hubei. Combined with the geographic and traffic location and tourism product characteristics of Hubei, we should further promote the cooperation in travel by high-speed rail. Under the framework of promotion alliance of travel by high-speed rail, we should amplification the one-city effect of tourist cities along the high-speed rail and speed up the arrangement of tourism products of trans-provincial travel by high-speed rail to strengthen the interaction of the tourists along the line. At the same time, we should expand the exchange and cooperation in the field of tourism development and management, and fully display the status and image of travel by high-speed rail in the national development pattern. We should also strengthen the tourism cooperation of the middle route of the South-to-North Water Transfer Project and combine the counterpart support of the water-receiving areas to the water resource areas with the tourism cooperation of the cities along the line, such as Beijing, Tianjin, Hebei, Henan and Hubei, so as to expand the levels and fields of tourism cooperation on the basis of complementary advantages of tourism products and overall interaction of tourists.

Give Play to the New Efficiency of the "One Belt and One Road" Tourism Resources. Based on the characteristics of tourism resources, the level of tourism development, the positioning of tourism pattern, the direction of tourism development in different regions of Hubei, for the overall linkage of the whole province, we should adjust measures to promote the development of urban tourism in Wuhan, ecological tourism in western areas, cultural tourism in central areas and human tourism in eastern areas according to local conditions. In accordance with the four-in-one mode of "core scenic spots, resort towns, tourist vacation base, tourist central cities", we should build ten new tourist areas, allowing visitors to experience the tourism consumption pattern of sightseeing within the scenic spots, enjoying comprehensive services outside, relaxing on holidays in towns/villages as well as gathering and distributing in urban areas.

Further Shape the Brand Image of Hubei Tourism. We should make further efforts to shape the brand image, explore the advantages and characteristics of Hubei tourism, enrich and expand the connotation of tourism brand in Hubei, and comprehensively expand the domestic and international tourism market. The tourism brand of "delicately beautiful Hubei" has played a positive role in the promotion of inbound travel in Hubei, but also showed limitations in many aspects. During the"13th Five-Year" period, Hubei province should establish a new tourism theme image on the basis of the trial promotion of the tourism brand of "Hubei, a bosom friend and attractive city". We should actively promote the following 12 tourism brands, namely the fashion river city of Wuhan, holy mountains in three-gorges areas, romantic charms of watery places, the celestial mountain of Wudang Mountain, the romantic Jingchu, the splendid three kingdoms (Wei, Shuhan and $\mathrm{Wu}$ ), the limpid rivers of Tujia and Miaojia minority, the towering Dabie Mountain, the first ancestor-Shennong, the paradise of Chan sect, the health care of hot spring and the ocean of flowers in four seasons etc.

Construct a General Intelligence Tourism System. We should construct public service platform, industry management platform and interactive marketing platform of intelligent tourism covering the whole of Hubei with the role of Wuhan as the hub and core tourism cities as the node. We should also promote the trial demonstration of intelligent tourism, giving support to Wuhan in 
the construction of a national pilot city of intelligent tourism and accelerate the provincial trial construction of intelligent tourism. Firstly, we should construct the public service platform of intelligent tourism to accelerate the development of tourism information service based on the Internet and mobile Internet, and gradually establish a service system combining traditional channels with new media channels such as micro-blog, Wechat, cell-phone APP etc. Moreover, we should improve the inquiry services of public tourism information, such as public tourism products and facilities, tourism complaints and rescue etc. Secondly, we should construct the industry management platform of intelligent tourism. We should construct the industry management platform, such as the tourism data center of Hubei, the statistics and analysis system of dynamic tourism data, the management and service system of tour group, the operation and monitoring system of tourism industry, and the electronic authentication system of tourism enterprises etc, so as to achieve the intelligent management and monitoring of tourism industry in Hubei and provide intelligence solutions all the way. Thirdly, we should construct the interactive marketing platform of intelligent tourism. We should encourage the development of tourism e-commerce, and actively promote the development of all kinds of online travel platform enterprises to support tourism enterprises, such as ECOTIC and Wuhan Tourism Development \& Investment Group Co., Ltd, to explore and develop such services as internet finance and e-card in tour etc and promote cross-industry innovative integration and development.

\section{Summary}

Under the drive of national strategy of "One Belt and One Road" at present, Hubei should seize the opportunity to strengthen the cooperation with countries and regions along the line in such fields as overall planning, integrating resources, joint marketing and innovating products. We should solve the problem of unbalanced development of regional tourism in Hubei from the perspective of international and inter-provincial tourism development market. Under the guidance of the development concept of "innovative, coordinating, green, open and shared", Hubei should adapt the new normal of economic development and fully integrate into the development strategy of "One Belt and One Road", so as to integrate resources and build the tourism industry a new highlight of the promotion of the national economic development. We should also seek a new model of regional tourism cooperation and development, and innovate the levels and fields of Hubei "One Belt and One Road" tourism cooperation, give play to the efficiency of Hubei "One Belt and One Road" tourism resources, implement overall marketing, and share the development benefits, comprehensively promote the improvement of quality and efficiency as well as the transformation and upgrade of tourism industry, so as to make unceasing contribution for Hubei to build supporting points and take the lead and for China to become a powerful tourism country.

\section{Acknowledgements}

This research was financially supported by the Wuhan Donghu University youth social science fund project. One of the research results of Wuhan Donghu University youth social science fund project "Marketing research of Wuhan city circle as destination under the background of central China tourism integration".

\section{References}

[1] X.J Li, Economic Geography [M]. Higher Education Press, 2000. (In Chinese).

[2] E.Y Wang, R Zhao and X.L Zhang, Human Geography [M].Higher Education Press, 2013. (In Chinese).

[3] Y.C Qin, G.P Zhou and W.D Luo, One belt and one road Reader [M]. Zhejiang University Press, 2015. (In Chinese).

[4] LeiperN, Tourism Manager [M].Collinwgood, VIC: TAPE Publications, 1995. 
[5] Brain Hocking, Changing the terms of trade policing making from the club to the multitakeholder mode [M].London: Cambridge University Press, 2004.

[6] Z.T Liu, M Zhao, The Countermeasures for the development of a tourism industry in Jiangsu area [J]. Urban development strategy 2015.11(In Chinese).

[7] Y.L Zhang, Focus on The Belt and Road strategic. [J].Continental Bridge View, 2014. (In Chinese).

[8] Carla P.Freeman, Neighborly Relations: the Tumen development project and Chinas security stategy [J].Journal of Contemporary China(2010),19(63), January.

[9] Hidetaka, Yoshimatsu, Regional cooperation in Northeast Asia: search for the mode of governance [J].International Relations of the Asia-Pacific, 2010(10).

[10] Marija\&Dalibor Miletic. Competitiveness and Sustainable Development of Serbian Tourism [J].Procedia-Social and Behavioral Science 44.2012.

[11] Neelu Seetaram. Immigration and international inbour tourism: Empirical evidence from Australia [J].Tourism Management, 2012, 33(6).

[12] Y Liu, The path to enhance the overall competitiveness of the tourism industry under one Belt and one Road strategy [J].2015.8.

[13] S.T Cao, etc. Research on the innovation of tourism industry development in Hubei [J]. Theory Monthly, 2010(3). 